\title{
РАННЯЯ ЛИРИКА ЭДУАРДА БАГРИЦКОГО 1910 - 1920-Х ГГ. В КОНТЕКСТЕ ЖИЗНЕТВОРЧЕСКОГО ПРОЕКТА ПОЭТА
}

\author{
АЛЁНА Г. ШЕВЧЕНКО \\ Харьковский национальный педагогический университет имени Г. С. Сковороды \\ Факультет иностранной филологии \\ Кафедра практики английской устной и письменной речи \\ ул. Валентиновская, 2, 61000, Харьков, Украина \\ e-mail: alyonageorgievna@gmail.com \\ (получено 19.09.2017; принято 22.09.2017)
}

\section{Abstract \\ Eduard Bagritsky's early lyrics of 1910-s-1920-s in the context of the poet's project of life-creation (zhiznetvorchestvo)}

The article summarizes the results of research on Eduard Bagritsky's early lyrics in the context of his life-creation (zhiznetvorchestvo) project. Entering literature at the end of the Silver Age, Bagritsky belonged to the generation of postsymbolists who mastered poetic experience of previous literary trends, interpreted it in their creative work and expressed it in the way of life structured according to the laws of the new art. E. Bagritsky's lyrics and his life-creation (zhiznetvorchestvo) project of a «tramp» and a «fowler», opposed to the way of life of artists in first decades of the twentieth century, corresponded to the aesthetics of the era, in which not only former artistic searches, but also political and social standards were reviewed, the energy of destruction and the pathos of creation were combined. E. Bagritsky took an active part in creation of a «new» world and a «new» man, which was reflected in his creative work, connected with the traditions of Acmeism and Futurism. In addition to that, the way the course of social reorganization made some changes in his behavioral strategy, and reflected the crisis of his worldview. 


\section{Key words}

Life-creation project, behavioral strategy, lyrical hero, poet's image, sociocultural situation.

\section{Резюме}

В статье обобщаются результаты изучения ранней лирики Эдуарда Багрицкого в контексте его жизнетворческого проекта. Вошедший в литературу на излете Серебряного века, Багрицкий принадлежал к поколению постсимволистов, которое усвоило поэтический опыт прежних литературных течений, преломило его в своем творчестве и выразило в способе жизни, построенной по законам нового искусства. Лирика Багрицкого и его жизнетворческий проект «бродяги» и «птицелова», противостоящие жизнетворчеству художников первых десятилетий XX в., отвечали эстетике эпохи, в которой пересмотру подвергались не только прежние художественные искания, но также политические и социальные нормы, сочеталась энергия разрушения и пафос созидания. Багрицкий принимал активное участие в строительстве «нового» мира и формировании «нового» человека, что нашло отражение в его творчестве, связанном с традициями акмеизма и футуризма. Вместе с тем ход социального переустройства внес коррективы в его поведенческую стратегию, отразил кризис его мировоззрения.

\section{Ключевые слова}

Жизнетворческий проект, поведенческая стратегия, лирический герой, образ поэта, социокультурная ситуация.

Творчество Эдуарда Багрицкого (1895-1934) принадлежит к числу значительных явлений русской поэзии XX века. Им созданы стихотворения и поэмы, которые воплотили проблемы, возникшие после резкого революционного слома мира, и поиски новой гармонии. Вошедший в литературу на излете Серебряного века, Багрицкий принадлежал к поколению постсимволистов, которое усвоило поэтический опыт прежних литературных течений, своеобразно преломило его в своем творчестве и выразило в способе жизни, построенной по законам нового искусства. Сформированный в атмосфере пред- и послереволюционных лет, Багрицкий принимал активное участие в строительстве «нового» мира и формировании «нового» человека, что, несомненно, нашло отражение в его творчестве, поначалу связанном с традициями акмеизма и футуризма. Вместе с тем ход социального переустройства, свидетелем которого поэт стал в 1930-е гг., существенно повлиял на тематику его произведений, внес коррективы и в его поведенческую стратегию, отразил кризис его мировоззрения. 
Однако история изучения этой проблемы свидетельствует о том, что лирика поэта, как правило, осмыслялась наряду с молодой «комсомольской» поэзией 1920-х гг. и в связи с романтизмом и романтикой, что внесло терминологическую путаницу и исказило историко-литературную перспективу. В нашей статье речь идет о том, что плодотворным для ее изучения является контекст жизнетворчества поэта. Это позволяет пересмотреть устоявшиеся и порой ошибочные представления о роли и месте его поэзии в литературе 1920-1930-х гг. Под жизнетворчеством в этом случае мы понимаем, вслед за Е.А. Бычковой, «сознательное структурирование своего жизненного пути, реализация в своей биографии некоего выбранного канона, личной легенды конкретного человека» ${ }^{1}$ Рассмотренная в таком аспекте, лирика Э. Барицкого предстает как один из важнейших факторов воплощения утопического жизнетворческого проекта, направленного, в отличие от предшественников, не на торжество Красоты и Добра, а на установление мира всеобщей Справедливости и Свободы.

Творческое наследие Эдуарда Багрицкого становилось предметом изучения неоднократно ${ }^{2}$, однако к середине $1990-$ х гг. интерес к творчеству Багрицкого заметно снизился. В учебниках, вышедших в свет в начале нынешнего века, творчество Багрицкого зачастую представляется упрощенно. Его безосновательно упрекают в антигуманизме, пропаганде революционного насилия, которому должно быть подчинено все. Вместе с тем в последние годы кроме односторонних и прямолинейных оценок предприняты попытки предложить новые подходы к прочтению известных стихотворений․․ Многие наблюдения иссле-

1 Е.А. Бычкова. Жизнетворчество как феномен культуры декаданса на рубеже ХІХ-ХХ веков. Диссертация на соискание ученой степени кандидата культурологии. Специальность 24.00.01 - «Теория и история культуры». Москва, 2001, с. 9.

2 В.Б. Азаров. Багрицкий и современность. «Новый мир» 1948, № 7, с. 201-214; В.Б. Азаров. Пушкинская тема в творчестве Багрицкого. «Литературный современник» 1937, № 1, с. 169-174; Л.Э. Аннинский. Багрицкий: «... и труба пропела». «Литературная учеба» 2003, № 5, с. 178-195; Л. Аннинский. Са-пож-ни-ки... «Родина» 2010, № 3, с. 23; П.Г. Антокольский. Путь поэта. [В:] Эдуард Багрицкий: воспоминания современников. Москва: Советский писатель, 1973, с. 3; П.Г. Антокольский. Эдуард Багрицкий. [В:] П.Г. Антокольский. Поэты и время. Москва: Советский писатель, 1957, с. 85-99; К.М. Бугаева. К вопросу об эволюичии романтизма Э. Багриикого. «Вопросы русской литературы» 1966. Вып. 2, с. 73-78; И. Волгин. Эдуард Багриикий. [В:] Стихотворения и поэмы. Сост., вступ. ст. и прим. И.Л. Волгина. Москва: Правда, 1987, с. 5-20; И. Гринберг. Эдуард Багриикий: Творческий путь поэта. Ленинград: Художественная литература, 1940; И. Гринберг. Эдуард Багрицкий. [В:] Э. Багрицкий. Стихотворения и поэмы. Авт. вступ. ст. И. Гринберг. Сост. и подгот. текста В. Азарова, Е. Бургункер. Москва: Художественная литература, 1956, с. 5-35; Е.П. Любарева. Советская романтическая поэзия (Н. Тихонов, М. Светлов, Э. Багриикий). 2-е изд. Москва: Высшая школа, 1973; Е.П. Любарева. Эдуард Багриикий: Жизнь и творчество. Москва: Советский писатель, 1964; И.С. Рождественская. Поэзия Эдуарда Багрицкого. Ленинград: Художественная литература, 1967; А.Д. Синявский. Эдуард Багрицкий. [В:] История русской советской литературы. Т. 1. Москва: Издательство АН СССР, 1958, с. 397-420.

3 Л. Аннинский. Эдуард Багрицжий: «...и труба пропела». [В:] Л. Аннинский. Красный век. Эпоха и ее поэты. В 2 книгах. Москва: ПРОЗАиК, 2009. [Online:] <https://coollib.com/b/212252/ read\#t16> (20.08.2017); Р.В. Банчуков. Одесса - Кунцево - Вечность. [В:] Люди. Peoples.ru. [On- 
дователей подтверждают плодотворность рассмотрения лирики Э. Багрицкого в контексте жизнетворчества поэта.

Проблема жизнетворчества в отечественной и зарубежной науке ставится и решается, как правило, на материале литературы немецкого романтизма, западноевропейского декадентства и русского символизма. Большое количество работ, посвященных этой проблеме, позволяет говорить об основательной изученности этого феномена (Н. Богомолов ${ }^{4}$, Г. Винокур ${ }^{5}$, О. Вайнштейн ${ }^{6}$, Т. Никольская ${ }^{7}, 3$. Минц $^{8}$, В. Паперный ${ }^{9}$, Е. Обатнина ${ }^{10}$ и др.). О жизнетворчестве младших символистов и поэтов русского авангарда пишет Д. Иоффе ${ }^{11}$; жизнет-

line:] <http://www.peoples.ru/art/literature/poetry/contemporary/eduard_bagritskiy> (20.08.2017); П. Баренбойм. Тиль Уленшпигель времен сталинизма. «Время новостей» 2010, 16 февраля; В. Домиль. Удивительный мир Эдуарда Багрицкого. «Секрет» 2010, 6 августа. [Online:] <http:// bagritsky.ru/articles/Udivitelnyy_mir_Aeduarda_Bagritskogo/> (20.08.2017); М.П. Загребельный. Эдуард Багрицкий. Харьков: Фолио, 2012. [Online:] <http://modernlib.ru/books/m_p_zagrebelniy/eduard_bagrickiy/read_1/> (20.08.2017); Е. Каракина. По следам Юго-Запада. [Online:] $<$ http://www.belousenko.com/books/litera/karakina_south_west.htm> (20.08.2017); Е. Каракина. Птииелов в сетях. «Предлог» 2000, № 2, с. 180-188; Е.А. Ковалева. Лексический аспект железнодорожной ситуации в поэзии Э. Багриикого. [В:] Масловские чтения. Мурманск: Издательство Мурманского университета, 2007, с. 231-235; А.А. Малиновский. Э. Багрицкий. «Кочки». «Русский язык в школе» 2014, № 2, с. 42-45; Е. Михайлик. «Карась» глазами рыбовода. «Новое литературное обозрение» 2007, № 87, с. 104-112; Н.А. Петрова. Но иногда глаза он раскрывал. Февраль и Октябрь в поэзии Эдуарда Багрицкого. «Вестник Томского государственного университета. Филология» 2010, № 4 (12), с. 86-94; И. Поступальский. Стихи. Воспоминания о Багрицком. Вступ. слово, публ. и ком. С. Зенкевича. «Журнальный зал. Арион» 2015, № 4. [Online:] <http://magazines.russ.ru/arion/2015/4/22p.html> (20.08.2017); С. Стратановский. Возвращаясь к Багрицкому. «Звезда» 2007, № 2, с. 191-208; И. Фаликов. Кидайся в края...: заметки о Багрицком. «Культура» 2004, 13-19 мая, с. 5; В. Шохина. Ангел смерти в кожаной тужурке. «Частный корреспондент», 3 ноября 2014. [Online:] <http://www.chaskor.ru/article/ angel_smerti_v_kozhanoj_tuzhurke_20802> (20.08.2017).

4 Н.А. Богомолов. «Мы два грозой зажженные ствола...». [В:] Анти-мир русской литературы: язык, фольклор, литература. Москва: Ладомир, 1996, с. 309-337.

5 Г.О. Винокур. Биография и культура. Русское сиеническое произношение. Москва: Русские словари, 1997, с. 17-23.

6 О. Вайнштейн. Жизнетворчество в культуре европейского романтизма. «Вестник РГГУ». Вып. 2: ИВГИ за письменным столом. Под ред. С.Ю. Неклюдова. Москва: Российский государственный гуманитарный университет, 1998, с. 161-186.

7 Т.Л. Никольская. Творческий путь Л.Д. Зиновьевой-Аннибал. [В:] А. Блок и революиия 1905 года. Блоковский сборник 7. Тарту, 1988, с. 123-139.

8 З.Г. Минц, Ю.М. Лотман. Статьи о русской и советской поэзии. Таллинн: Ээсти Раамат, 1989.

9 В.М. Паперный. Из наблюдений над поэтикой Андрея Белого: лищемерие как текстопорождающий механизм.«Славяноведение» 1992, № 6, с. 39-44.

10 Е.А. Обатнина. А.М. Ремизов: жизнетворчество entrechienetloup. «Пограничное сознание. Альманах» 1999. Вып. 5. Санкт-Петербург, с. 397-424.

11 Д. Иоффе. Жизнетворчество русского модернизма subspeciesemioticae. Историографические заметки к вопросу типологической реконструкиии системы жизнь-текст. «Критика и семиотика» 2005. Вып. 8, с. 126-179. 
ворчеству как феномену культуры декаданса рубежа XIX-XX веков посвящена работа Е. Бычковой ${ }^{12}$; жизнетворческому проекту М. Пришвина - статья Е. Худенко $^{13}$; жизнетворчество Н. Гумилева рассмотрено в работе А. Кулагиной ${ }^{14}$. Обобщение современных представлений о сущности и особенностях жизнетворчества дает возможность реконструировать основные аспекты жизнестроительного проекта Э. Багрицкого. На наш взгляд, рассмотрение его лирики в таком контексте позволит решить вопрос о месте романтики в ней, пояснить эволюцию его творчества, сделать выводы о проблемно-тематическом и поэтологическом своеобразии лирики.

Эдуард Багрицкий впитывал черты предшествующей культуры, прежде всего, доминантные элементы жизнетворчества романтиков и символистов, но формировался на их отрицании как стратегии поведения по модели «художник - бродяга» в варианте «художник (поэт) - птицелов». В жизнетворческом проекте Багрицкого очевидны типичный склад поведения, специфические формы общения и внешнего самовыражения, соответствующие новому пониманию функции поэта и поэзии. Для него характерны равнодушие к материальному, подчеркнутая нелитературность речи и неизысканность поведения, книжный характер ранней поэзии и представление о ее «всемирном» предназначении; «естественная» театрализация, участие в публичных акциях и собраниях поэтов как инвариант «богемной» жизни; использование для общения с любимой женщиной кратких форм, не терпящих внешнего выражения чувств; деэстетизация жизни. В московский период жизни игровой характер поведения поэта претерпевает изменения вследствие столкновения с меняющейся социокультурной ситуацией. Если исходить из принятого нами понимания феномена жизнетворчества, его элементами являются сознательный подход поэта к выбору поведенческой стратегии и ориентация на некий канон, подсказывающий пути пусть и не сознательного, но формирования собственной «легенды». На наш взгляд, в биографии и творчестве Э. Багрицкого очевидны эти особенности, дающие возможность пояснить и уточнить проблематику стихотворений, нередко вызывающих сложности в понимании и произвольные истолкования. Такой подход особенно плодотворен при обращении к ранней лирике поэта 1910-1920-х гг., названной нами лирикой ученического периода. В ней ощутимо влияние поэзии акмеизма и футуризма.

Первые стихотворения поэта публиковались в 1915 году в альманахах: «Серебряные трубы» (1915), «Авто в облаках» (1915), «Седьмое покрывало» (1916) и газете «Южная мысль» (1915). Как писал И. Волгин, в ту пору

12 Е.А. Бычкова. Жизнетворчество как феномен культуры декаданса на рубеже ХІХ-ХХ веков. Диссертация на соискание ученой степени кандидата культурологии. Специальность 24.00.01 - «Теория и история культуры». Москва, 2001.

13 Е.А. Худенко. Жизнетворчество М.М. Пришвина: игровая стратегия. [Online:] <http:// elar.urfu.ru/bitstream/10995/18695/1/iurg-2011-87-10.pdf> (20.08.2017).

14 А.А. Кулагина. Жизнетворческая концепиия и принципы создания образа в лирике и драматургии Н.С. Гумилева. Диссертация на соискание ученой степени кандидата филологических наук. Специальность 10.01.01 - «Русская литература». Москва, 2012. 
стихи читались со всех эстрад: поэзия была разлита в воздухе. И когда летом 1914 года предприимчивый одесский фельетонист Пильский возил по дачным пригородам ватагу пользующихся неизменным успехом молодых дарований (среди которых первенство по праву принадлежало 18-летнему автору “Креолки”), <..> Если там, на севере, выходят нашумевшее „Облако в штанах” или какой-то необыкновенный „Близнец в тучах”, то почему бы и здесь, на юге, не завести свое собственное издание - с не менее замечательным названием - „Авто в облаках”? Именно в этом альманахе появляются первые стихи Багрицкого $^{15}$.

Исследователи прежних лет эти стихотворения недооценивали. И. Гринберг полагал, что «подражательность стихов Багрицкого тех лет очевидна <...> Здесь нет еще собственного поэтического голоса; здесь налицо только копии с копий» ${ }^{16}$. В ранней лирике он справедливо обнаруживал «ритмы и образы, словно скопированные с “модели” - произведений Гумилева, Брюсова, Северянина, раннего Маяковского» ${ }^{17}$. В. Катаев относил к кругу чтения Багрицкого Стивенсона, Эдгара По, Бодлера, Верлена, Артюра Рембо, Леконта де Лиля, Эредиа, символистов, акмеистов и футуристов. Волгин считал Багрицкого «истинным знатоком русской и мировой поэзии. Мир прошлого и настоящего различается начинающим стихотворцем через этот магический кристалл» ${ }^{18}$. Потому естественно, что в его поведенческой стратегии обнаруживаются признаки контаминации разных элементов романтической модели, в которой очевидна стилизация предшествующей книжной культуры. Однако эта модель, на наш взгляд, воспринята молодым поэтом через посредничество западноевропейского символизма, в котором фигура поэта, его «поза» и «жест», а также тематика стихотворений говорили об исключительности, оторванности от постылого буржуазного быта. Как справедливо отмечал Волгин, «всей поэтической структуре» Багрицкого было присуще такое качество, как «естественная театральность»: «Каждый поэт в известной степени лицедей. Но Багрицкому свойственна театральность особо города. Он выкликает на поэтическую сцену не только своих любимых героев - бродяг, рыбаков, птицеловов, пиратов, контрабандистов и т.п. - он сам примеряет их экзотические одежды и принимает посильное участие в их забавах и гульбищах» ${ }^{19}$. Между подобным жизнетворческим приемом и реальной жизнью молодого поэта была, однако, огромная разница: Багрицкий жил в стесненных условиях еврейской местечковой среды, боялся воды и никогда не купался в море, никуда не выезжал из Одессы.

В ранних стихотворениях вместе с тем проявлялись и индивидуальные художественные решения молодого поэта. Сам поэт, как известно, связывал свое творчество именно с акмеизмом и считал своими учителями Вл. Нарбута и М.

15 И. Волгин. Эдуард Багрицкий. Стихотворения и поэмы. Сост., вступ. ст. и прим. И.Л. Волгина. Москва: Правда, 1987, с. 8.

16 И. Гринберг. Эдуард Багрицкий. Стихотворения и поэмы. Авт. вступ. ст. И. Гринберг. Сост. и подгот. текста. В. Азарова, Е. Бургункер. Москва: Художественная литература, 1956, с. 6-7.

17 И. Гринберг. Эдуард Багриикий. Стихотворения и поэмы..., с. 7.

18 И. Волгин. Эдуард Багриикий. Стихотворения и поэмы..., с. 6.

19 Там же, с. 9. 
Зенкевича. Увлечение Багрицкого новейшими поэтическими исканиями и создание собственной поведенческой модели не было чем-то исключительным. Лирический герой молодого поэта И. Эренбурга в цикле Туберозам (1910), написанном под влиянием символистской поэзии, признавал, что со своими романтическими взглядами «на пять столетий опоздал»:

В одежде гордого сеньора

На сцену выхода я ждал,

Но по ошибке режиссера

На пять столетий опоздал ${ }^{20}$.

Позднее Эренбург вспоминал:

Русский юноша девятнадцати лет, жадно мечтавший о будущем, оторванный от всего, что было его жизнью, решил, что поэзия - костюмированный бал. Мне действительно тогда казалось, что я создан, скорее, для крестовых походов, нежели для высшей школы социальных наук. Стихи получились изысканные; мне теперь неловко их перечитывать, но писал я их искренне ${ }^{21}$.

Думается, это признание может объяснить и юношеские поэтические пробы Багрицкого. Так, В. Катаев приводил четверостишие из его стихотворения, написанного до публикации первых стихов в печати, которое он относил к 1912 или 1913 году, и в котором очевидно типологическое сходство с ранним стихотворением Эренбурга:

Нам с башен рыдали церковные звоны,

Для нас поднимали узорчатый флаг,

Но мы заряжали, смеясь, мушкетоны

И воздух чертили ударами шпаг ${ }^{22}$.

Д. Мирский писал, что «первое двустишие точно воспроизводит ритм, движение и декорацию „Города женщин” Брюсова, второе - столь же точно „Капитанов" Гумилева, тогда еще только начинавшего завоевывать сердца молодых поэтов. Но оба двустишия вместе - не Брюсов и не Гумилев. В них есть уже предчувствие позднейшей бунтарской тематики Багрицкого...» ${ }^{23}$. Наблюдение Мирского подтверждает заключительная строфа стихотворения, в которой возникает индивидуальный поэтический образ Летучего Голландца:

Когда погибал знаменитый «Титаник»,

Тогда твой мираж трепетал в небесах.

20 И. Эренбург. Стихотворения и поэмы. Вс. ст., сост., подг. текста и прим. Б.Я. Фрезинского. Серия «Новая библиотека поэта». Санкт-Петербург: Гуманитарное агентство «Академический Проект», 2000, с. 77.

21 И. Эренбург. Люди, годы, жизнь: Воспоминания: в 3 m. Т. 1. Вс. ст. Б.М. Сарнова, ком. Б.Я. Фрезинского. Изд. исправл. и доп. Москва: Советский писатель, 1990, с. 107.

22 В.П. Катаев. Алмазный мой венеи. Москва: Советский писатель, 1979, с. 182.

23 Д.П. Святополк-Мирский. Э. Багриикий. «Юго-Запад». [В:] Поэты и Россия: статьи. Рeиензии. Портреты. Некрологи. Санкт-Петербург: Алетейя, 2002, с. 133. 
Летучий Голландец! Чарующий странник!

Чрез вечность летишь ты на всех парусах! ${ }^{24}$

Поэт сближает в рамках одной строфы современность и прошлое, что создает объемную панораму исторического времени: «Титаник» потерпел крушение в 1911 г., однако эта катастрофа осмыслена как одна из череды таинственных кораблекрушений. Образ Летучего Голландца («чарующий странник») возвышен авторской увлеченностью.

На наш взгляд, Багрицкому было близко истолкование этого образа в романтическом духе западноевропейской литературы, выраженном в произведениях В. Скотта, В. Гауфа, Г. Гейне. Он также был знаком с оперой Р. Вагнера Летучий голландеи. В его архиве сохранилась рукопись под названием Вагнер, имеющая текстовые совпадения, которые позволяют рассматривать ее как один из вариантов поэтического цикла Сказание о море, матросах и Летучем Голландие. В тексте есть строка «Вагнеровский двинулся прибой», отсылающая к опере немецкого композитора. Этот поэтический образ, родившийся как отражение воплощенного в литературе и музыке образа, становится сквозным в лирике поэта. В стихотворении Конеи, Летучего Голландиа (1915) ощутимо его новое звучание. Он возникает в заглавии и в последней строфе, окружающих сниженное, прозаическое изображение припортового города, района, прилегающего к пристани, и его обитателей. «Конец» легенды прочитывается в поэтических образах, обытовляющих обычно возвышенные приметы мира в его романтической интерпретации: «надтреснутых гитар», «дребезжащи звуки», «охрипшая труба», «костлявые безжалостные руки», таверна заброшенная, матрос напившийся, бранятся два пьяных боцмана, «струится липкий чад», «весь в пятнах от вина передник толстой Марты». Однако во второй части стихотворения поэт отдает дань модернистской эстетике:

Береты моряков обшиты галунами,

На пурпурных плащах в застежке - бирюза.

У бледных девушек зеленые глаза

И белый ряд зубов за красными губами...

Фарфоровый фонарь - прозрачная луна,

В розетке синих туч мерцает утомленно,

Узорчат лунный блеск на синеве затона... ${ }^{25}$

Образ Летучего Голландца, которому нет места в житейской, сниженной картине мира, трансформируется - он не преследует корабли, не символизирует их погибель:

Безумный старый бриг Летучего Корсара

Раскрашенными флагами поник ${ }^{26}$.

24 Д.П. Святополк-Мирский. Э. Багрицкий. «Юго-Запад»..., с. 134.

25 Э.Г. Багрицкий. Собрание сочинений: в 2 m. Т. 1: Ранние стихи. Октябрь. Море. Трактир. Юго-Запад. Под ред. И. Уткина. Вступ. ст. Ю. Севрука. Москва-Ленинград: ГИХЛ, 1938, с. 228. 26 Там же. 
Сквозной характер образа Летучего Голландца подчеркивает его возникновение в целом ряде стихотворений. Так, на литературном вечере 2 марта 1923 г. поэт прочел недавно завершенную поэму Сказание о море, матросах и Летучем Голландие, которая была опубликована в одесском журнале «Силуэты». Багрицкий предпослал тексту своего произведения своеобразное поэтическое предисловие. Оно не вошло в опубликованный текст, в сборниках же стихотворений Багрицкого иногда печатается в примечаниях и поясняет не только глубинный смысл самого произведения, но и стихотворений Пушкин и Александру Блоку. У Багрицкого лирический герой, уподобленный коту, волочит по камням цепь, явно символизирующую пролеткультовские догмы, и «цепь грохочет влево, влево, / Не смей направо повернуть!». Между тем он по-прежнему ощущает себя поэтом-бродягой - «Довольно! Или не бродячий / Мне послан Господом удел?», - который скитается уже не по рощам и полям, наблюдая птиц, а по фронтам гражданской войны. Лирический герой отстаивает свое право на поэзию, которая была его оружием:

Когда в госпиталях тифозных

Я Блока для больных читал...

Пусть, важной мудростью объятый,

Решит внимающий совет:

Нужна ли пролетариату

Моя поэма или нет! ${ }^{27}$

Как известно, это произведение Багрицкий не публиковал в своих сборниках стихотворений.

Полемика о месте творчества Багрицкого в культуре пролетариата смещается в сторону размышления о роли поэзии в целом, о ее инструментарии и функции. Ю. Олеша в своих воспоминаниях писал:

Когда-то, очень давно, Багрицкий рассказывал мне об одном своем замысле. "Представь себе... Летучий Голландец... он входит в харчевню. Деревянный стол. Девушка. Он кладет на стол розу. И вдруг все видят: начинается превращение розы... Сквозь нее проступают очертания города... Люди видят город...” Я не помню, что рассказывал он дальше. Когда мы хоронили Багрицкого, я вспомнил эту импровизацию замечательного романтика. Ведь это же и есть сущность искусства - эти превращения! Ведь это же и есть сила искусства - превратить материал своей жизни в видение, доступное всем и всех волнующее... ${ }^{28}$

На наш взгляд, Ю. Олеша говорит именно о жизнетворчестве («превратить материал своей жизни в видение»), в котором осуществляются превращения жизненного материала в поэзию, а жизни - в «текст» искусства.

Стихотворения молодого Багрицкого, появившиеся в одесских изданиях в 1915 г., писались под мощным влиянием модернистских поэтических исканий. Поэт экспериментировал, перебирал разные темы, связанные с его книжными

27 Э.Г. Багрицкий. Собрание сочинений: в 2 m. Т. 1: Ранние стихи. Октябрь. Море. Трактир. Юro-Запад..., с. 508.

28 Ю.К. Олеша. Ни дня без строчки: воспоминания. [В:] Ю.К. Олеша. Зависть. Три толстяка. Ни дня без строчки. Москва: Художественная литература, 1989, с. 222. 
впечатлениями, а также апробировал разные поэтологические приемы. Стремление к вещности, воспринятой им от акмеизма, распространяется не только на изображение мира природы, но и на постижение сущности человека. В стихотворении Суворов, отмеченном многими критиками и исследователями, проявляется намеренный отказ от героизации образа великого полководца, сосредоточение внимания на материальных деталях, вещах, создающих впечатление «натуралисто-реалистического», по выражению В. Нарбута, описания:

В серой треуголке, юркий и маленький,

В синей шинели с продранными локтями, -

Он надевал зимой теплые валенки

И укутывал горло шарфами и платками ${ }^{29}$.

Слава великого полководца уже катилась по России: заслышав рожок его почтовой кареты, поднимались шторы, смолкало пение и звучал восторженный шепот: «Едет Суворов!». Поэт воссоздает ясные и точные детали и завершает стихотворение там, где другие поэты обычно его начинали: парадный образ Суворова ему не интересен. Как отмечает Л. Аннинский,

реальный Суворов, прошедший огни и воды, солдатски быстрый, закаленный, прицельно очный в глазомере, мало похож на старика, хватающегося за перила в стихе Багрицкого, но энергия стиха таится именно в обороте реальности и выдуманности: ход оборотня как раз и делает “Суворова” шедевром раннего Багрицкого... ${ }^{30}$

Поэтическое новаторство Э. Багрицкого оказало влияние на последующие интерпретации этого образа (например, К. Симоновым).

В тот же период Багрицкий пишет стихотворение Гимн Маяковскому (1915), уже привлекавшее внимание исследователей ${ }^{31}$. Творчество В. Маяковского захватывало внимание молодого поэта - он является последователем Маяковского прежде всего в тематике: под влиянием современника в его поэзию приходит урбанистическая тема (Дерибасовская ночью, Порт). Поэту были знакомы написанные В. Маяковским к этому времени Владимир Маяковскиц̆, Я и Наполеон, Вам!, Гимн судье, Гимн ученому. Используя в заглавии своего стихотворения слово «гимн», Багрицкий не подражал Маяковскому, а нашел собственное наименование, подразумевающее прославление современника, содержащее «обращения и воззвания к восхваляемому объекту, хвалебные сравнения и описания» ${ }^{32}$ и т.п., - Маяковский ввел в заглавие своих стихотворений слово «гимн» позднее.

29 Э.Г. Багрицкий. Собрание сочинений: в 2 m. Т. 1: Ранние стихи. Октябрв. Море. Трактир. Юro-3апад..., с. 231.

30 Л.Э. Аннинский. Багрицкий: «... и труба пропела». «Литературная учеба» 2003, № 5, с. 180.

31 С. Гехт. Эдуард Багрицкий. [В:] Э.Г. Багрицкий. Избранное. Москва: Правда, 1939, с. 3-12; А. Горелов. Маяковский и Багриикий. Идеи и образы. [В:] А. Горелов. Бесстрашие художника. Ленинград: Издательство писателей, 1935, с. 54-70; И.Т. Крук. Забытые страницы Э. Багрицкого. «Вопросы русской литературы». Вып. 1 (4). Львов: Издательство Львовского университета, 1967, с. 47-53; 3.Г. Минц. Раннее творчество Эдуарда Багриикого. «Вестник ЛГУ» 1948, № 6, с. 109-118; Ю.К. Олеша. Об Эдуарде Багрииком. «Литературный критик» 1934, № 3, с.84-91.

32 Литературная энциклопедия. Т. 2. Москва: Сов. энциклопедия, 1929, с. 534. 
Гимн Маяковскому, по нашему мнению, свидетельствует о новой доминанте в поэтических исканиях Багрицкого - футуристической. Используя отдельные приемы поэтов этого течения, образный строй, ритмику, поэт сумел создать произведение в духе футуристской эстетики. Стихотворению присущи прозаизация предметов изображения, концентрация поэтических образов, всеобъемлющие олицетворения. Из ранней лирики Маяковского в стихотворение Багрицкого переходят образы города и осуществляется углубление, конкретизация образности, воспринятой от него. Образ «трубы, ловящие, как руки, облака» восходит и к «флейте водосточных труб» из стихотворения $A$ вы могли бы?, и к образу стекающих с крыши в трубы слез (Кое-что про Петербург), и к образу «встающих звезд», ноги которых «оперлись» на перину, и пр. Образ гиганта, который «ударил землю кованым каблуком», подсказан, вероятно, образом Маяковского из Уличного - «Вбиваю гулко шага сваи»; а оранжевый цвет костюма «вселенского спортсмена» вырастал из усиления цвета, используемого Маяковским для описания города: «желтую кофту из трех аршин заката», «золоченой буквы», «золотокудрые брюквы», «раздали горящие желтые карты» окнам, «как желтые раны, / огни обручали браслетами ноги». Роднит Гимн Маяковскому Багрицкого с поэзией современника и образ огромного в своих масштабах лирического героя, который запечатлен в ряде ранних стихотворений Маяковского. Стихотворение Багрицкого открывает целый тематический цикл произведений русских поэтов, посвященных Маяковскому (А. Ахматова, Н. Асеев, М. Цветаева). Как точно комментирует это стихотворение Л. Аннинский,

крутая талантливость, дымящаяся в этих строках, не мешает нам разглядеть несомненную выдуманность фигуры патриция, у коего „математика и история” на самом-то деле укладываются в курс реального училища, дополненного училищем землемерным, а изнеженность - плод упоенного чтения мировой мифологии и декадентской поэзии, помогающих вытеснить из сознания действительно ненавидимую Современность ${ }^{33}$.

Однако эта фигура вполне укладывается в поведенческую стратегию молодого поэта, уточняющуюся под влиянием его поэтических исканий.

О них свидетельствует попытка из экзотической легендарности обратиться к легендарности национальной в стихотворениях Славяне и Враг. Они создавались на фоне событий Первой мировой войны, когда в свет выходили сборники Славянские военные песни и Богатырские военные песни, в которых война истолковывалась как исполнение тысячелетней миссии России. Именно так осмыслена эта война В. Брюсовым, в поэтической интерпретации которого очевидна связь с его исторической концепцией и новая война представлена здесь абстрактным, а не живым драматическим событием. Подтверждением этому может служить и его стихотворение Cmaрый вопрос (1914), уже своим названием отсылающее к проблеме места и роли России в мировых процессах. Багрицкий осмысляет войну иначе. Центральным для его стихотворения становится

33 Л. Аннинский. Эдуард Багрицкий: «...и труба пропела». [В:] Л. Аннинский. Красный век. Эnоха и ее поэты. В 2 книгах. Москва: ПРОЗАиК, 2009. [Online:] <https://coollib.com/b/212252/ read\#t16> (20.08.2017). 
образ славянского бога Перуна, покровителя военной дружины. Однако поэт десакрализует его, трижды называя «безумным» и описывая посвященные ему пышные и жестокие обряды. Сближается с этим произведением и стихотворение Багрицкого Враг. Прозаизация традиционной военной темы, своеобразный взгляд на образ врага и войны, выраженные Багрицким, были восприняты поэтами-современниками и использованы в лирике 1940-х гг.

Индивидуальное своеобразие поэзии Багрицкого раннего периода также обусловил образ Тиля Уленшпигеля, связывающий между собой поэзию и поведенческую стратегию поэта. Как вспоминала Л. Багрицкая, «роман де Костера был настольной книгой поэта, а фольклорные образы Тиля Уленшпигеля и его закадычного друга, весельчака и ленивца Ламме, ставшего носителем идеи народного возмездия, - любимыми героями Багрицкого» ${ }^{34}$. Но не только героями: по нашему мнению, они стали неотъемлемыми элементами канона жизнетворчества, на которые ориентировался поэт. «Тиль Уленшпигель и Ламме Гоодзак слились в нем в одно», - полагала 3. Шишова ${ }^{35}$. А. Адалис даже утверждал, что поэту «хотелось жить так, как жили герои его стихов - замечательные малые: Робин Гуд и Эдвин, и Ламме Гоодзак, и сам Уленшпигель - бродяги и бунтовщики» ${ }^{36}$. Это подтверждает наше предположение о создании жизнетворческого проекта Багрицкого по модели «художник - бродяга». На наш взгляд, стихотворения, в которых возникает этот образ, целесообразно рассматривать как цикл. В нем циклообразующими элементами является образ Тиля Уленшпигеля, который сближается с лирическим героем, сквозная тематика, текстуальные совпадения, использование экспозиции, внешне не связанной с проблематикой стихотворений.

Стихотворение Тиль Уленшпигель датировано 1918 г. и 1926 г. Первая редакция этого стихотворения напечатана в одесских «Силуэтах», а позднее, в существенно переработанном виде, вторая редакция публиковалась в «Красной нови» и в сборнике «Юго-Запад». Стихотворение открывается обширной экспозицией, являющейся описанием кухни. Это описание напоминает фламандскую живопись, с которой неоднократно сравнивали стихотворения Багрицкого. В ней с помощью крупных, ясных и выпуклых образов представлена картина приготовления пищи. Описание кухни представляется нам искусной стилизацией, которая создает мир прошлого, причем мир, в котором контаминируются детали книжной реальности и современности. Лирический герой переключает внимание с кухни, где готовится пища, на себя:

Я в этот день по улице иду,

На крыши глядя и стихи читая, -

34 Эдуард Багрицкий: воспоминания современников. Сост. Л.Г. Багрицкая. Москва: Советский писатель, 1973, с. 535.

35 Эдуард Багриикий: Альманах. Под ред. В. Нарбута. Москва: Советский писатель, 1936, c. 202.

36 Там же, с. 211. 
В глазах рябит от солнца, и кружится

Беспутная, хмельная голова ${ }^{37}$.

В стихотворении возникает образ «бродяги», важный и для самохарактеристики героя, а сближение лирического героя и Тиля Уленшпигеля происходит не путем осознания каких-либо сходных черт, а путем наделения его собственными чертами. Таким образом, Тиль Уленшпигель является не только бродягой, как и лирический герой, но и поэтом, как он. В образе лирического героя подчеркнуты особенности, характерные и для поэта: «Пускай голодный я стою у кухонь», «Пускай истреплется моя одежда, / И сапоги о камни разобьются», а также дух вольнолюбия, сопряженный с близостью к людям. Во вторую редакцию стихотворения, опубликованную в «Красной нови», были внесены изменения. В первой редакции призыв к упокоению относится к бродяге, который в своей жизни много пил; во второй вместо образа бродяги поэт вводит образ товарища, который не много пил, а много пел о свободе. В первой редакции речь шла о могиле бродяги Уленшпигеля, а во второй - об упокоении лирического героя, посвятившего себя «песне и свободе».

Образ Тиля Уленшпигеля создан и в двух стихотворениях, написанных в конце 1922 г. и опубликованных одновременно: в новогодних номерах «Моряка» за 1923 г. и «Известиях Одесского губисполкома...» с одинаковыми заглавиями Тиль Уленшпигель. Монолог. В стихотворении Тиль Уленшпигель. Монолог («Отец мой умер на костре, а мать...») создается стилизация, в которой события, происходящие с лирическим героем, связаны с книжной основой. Однако поэт причудливо переосмысливает ее, отождествляя книжного и лирического героя, говорящего от первого лица.

Я - Уленшпигель. Нет такой деревни,

Где 6 не был я; нет города такого,

Чьи площади не слышали 6 меня.

Он близок к народу, к «добрым фламандцам», он «всем знаком». Герой пробуждает в сердцах, заплывших жиром и привыкшим мечтать лишь о пиве и душистом супе, «дух вольности и гордости родной». Он зовет кузнецов не починять кастрюли, а ковать мечи и наконечники для копий, он зовет корабельщиков построить корабль освобождения, солдат - не «почесывать затылки, / Дыша вином у непотребных девок», а готовиться к бою. Он дважды произносит пароль гезов, которые вели борьбу против испанского владычества, отвечая на посвист жаворонка криком петуха. Этот крик упоминался уже в первом стихотворении и возникает в финале, обращенном к испанскому полководцу Альбе ${ }^{38}$. Во втором стихотворении Тиль Уленшпигель. Монолог («Я слишком слаб, чтоб латы боевые...») лирический герой признается в неспособности воевать на поле брани, потому его оружием становится искусство - поэзия, живопись, музыка: «Веселые я выдумаю песни», «на заборе нарисую», «перебирая струны, запою».

37 Э.Г. Багрицкий. Собрание сочинений: в 2 m. Т. 1: Ранние стихи. Октябрь. Море. Трактир. Юro-3anad..., c. 51-52.

38 Там же, c. 290-291. 
К циклу стихотворений о Тиле Уленшпигеле, по нашему мнению, относится также стихотворение Ламме («В осенний день над площадью стоит»). Обычно оно публикуется отдельно от остальных произведений. Только в издании незавершенного двухтомного Собрания сочинений (1938) они публиковались как цикл ${ }^{39}$. Как известно, между стихотворениями Ламме и Встреча есть текстуальные совпадения, но, на наш взгляд, их следует рассматривать не как разные редакции одного стихотворения, а как два разных произведения, связанных между собой тематически. Как и прежние стихотворения цикла, Ламме начинается экспозицией, в которой представлено выразительное описание базарной площади. На ней продаются «осенние дары воды и суши»: полный соком виноград, пыльно-фиолетовые сливы, плетеные корзины с яблоками, золотистый перелив которых «озаряет» корзины, распластанные камбалы, грудой наваленный творог, нежно тающее масло, подвешенные на крючках мясные туши. Лирический герой, оглядывая эти богатства, думает о своем друге: «О, где же ты, широкоплечий Ламме - Великий мастер кухни и корчмы?» ${ }^{40}$ Образ толстяка Ламме, несущего гогочущего гуся и корзину с разнообразной снедью, символизирует собой возникавшую во всех стихотворениях цикла тему освободительной борьбы вольнолюбивых фламандцев, обозначаемую через свист жаворонка и крик петуха. Стихотворение Встреча отличается от стихотворения Ламме существенно, прежде всего, описанием базара, свидетельствующим об изменении точки зрения лирического героя. Он смотрит на продающуюся еду с отвращением и, в отличие от описания кухни или базара в предшествующих произведениях, испытывает по отношению к еде кардинально иные чувства: он «заблудился в грудах помидоров», «средь арбузов не нашел дороги», «черешни завели меня в тупик», «стена творожная обстала», «обрывы сыра / Грозят меня обвалом раздавить» ${ }^{41}$. Масло, о котором герой говорил, что оно «нежно тает», теперь вот-вот «раскаленной жижей» «обдаст каменья - и зальет меня». Брюква - «синемордая, тупая», морковь - «крысья, узкорылая». Еда «неумолимо» навалена в корзины и телеги, раскидана по грязи в мешках. С особенным отвращением описаны продавцы, «хозяева еды», «вожди съедобных батальонов», «памятники пьянству и обжорству». Все здесь ему глубоко враждебно, он «один среди враждебной стаи / Людей, забронированных едою». Появление Ламме представляется здесь спасением героя, неожиданным подарком. Описание общения с ним значительно расширено, детализировано и осовременено. Вместо искусной стилизации, в которой Ламме и лирический герой находятся в условном прошлом времени, поэт переносит любимого героя в современность - ведет в погреб с надписью «Пивная госзаводов Пищетрест». Диалог между Ламме и лирическим героем касается позиции поэта. Ламме видит, что он потерял прежнюю готовность к борьбе, он «ослабел». Если в стихотворении 1923 г. появление Тиля Уленшпигеля было неожиданным, то здесь с помощью ряда сравнений, повторяющихся «Пока... Пока...» акцентируется другая мысль: он

\footnotetext{
39 Там же, с. 453-472.

40 Там же, с. 491.

41 Там же, с. 117.
} 
и не мог не появиться, поскольку он вечен. Потому заключительный стих Я Тиля Уленшпигеля пою! становится утверждением свободолюбивой идеи. В отличие от Ламме в этом стихотворении строка публикуется после отточия и завершается восклицательным знаком.

Образы Тиля Уленшпигеля и Ламме, восходящие к литературному претексту, заняли важное место в жизнетворчестве поэта. Созданный на основе книжного источника и с помощью его образов мир построен на борьбе бродяги и творца с несправедливостью. В нем приняты отвлеченные и простые истины, противостоящие стороны определены четко и ясно, друзья и враги легко различимы. Во Bcmрече ощутимы перемены, происходящие в сознании лирического героя: выходя за границы условного поэтического мира, он обнажает истинные значения предметов и событий. Раблезианская радость от образов еды сменяется отвращением к ним, поскольку книжный мир устроен по другим правилам, чем мир реальный. Ламме оказывается голосом совести, призывающим из условного мира борьбы за справедливость выйти в мир действительных социальных противоречий, где Тиль Уленшпигель остается символом постоянного сопротивления. Но тоска лирического героя этим все равно не искупается.

Еще один важный элемент жизнетворческого проекта Багрицкого - это образ Диделя, близкого лирическому герою и самому поэту - любителю и знатоку птиц. Впервые это имя появляется в рукописи, датируемой 1916-1917 гг. Эта рукопись утеряна, но воспроизведена в альманахе «Эдуард Багрицкий» ${ }^{42}$. Две песни, содержащиеся в рукописи, опубликованы в 1923 г. в газете «Моряк». Редакция «Библиотеки поэта» называет эти песни разными редакциями стихотворения Птицелов. Как в случае со стихами Ламме и Встреча, мы рассматриваем их в качестве самостоятельных произведений, связанных единством темы и имеющих текстуальные совпадения. Известное стихотворение Багрицкого Птицелов впервые опубликовано в 1927 г. в «Красной ниве», а также открывало сборник «Юго-запад». Стихотворение датировано автором 1918 г. В 1926 г. оно вписано в тетрадь под заглавием Дидель. На наш взгляд, очевидна тематическая перекличка между стихами о Диделе и стихотворением О любителе соловъев, опубликованном в 1915 г. в альманахе «Авто в облаках». Птицелов и стихотворения «диделевского цикла», по нашему мнению, должны рассматриваться в контексте произведений Багрицкого о птицах, особенную любовь к которым отмечают все исследователи его биографии и творчества.

В жизнетворческом проекте Багрицкого модель «художник - бродяга» имеет инвариант «поэт - птицелов». В стихотворении Тиль Уленшпигель («Отец мой умер на костре, а мать...») сам поэт использует именно этот образ: «...бродягептицелову, / Несущему на рынок свой улов...», так что сближение лирического героя с птицеловом совершенно органично. Здесь впервые возникает любовная тема, когда увлеченность героя птицами приносит страдание женщине, не умеющей занять их место в его сердце. Поэт и «бродяга - птицелов» оказывается неспособным к жизни на одном месте, к обычному человеческому семейному счастью. В первой песне («Ах, у Диделя в котомке») птицы упоминаются

42 Эдуард Багрицкий: Альманах..., с. 65. 
дважды: среди разных занятий Диделя - «гуляет по полям», «смотрит в небо», «смеется невзначай», «свищет птицам». Затем эти же слова возникают в повторяющейся строфе:

Марта, Марта, надо ль плакать,

Если Дидель ходит в поле,

Если Дидель свищет птицам

И смеется невзначай ${ }^{43}$.

Эта строфа тематически сближается со стихотворением О любителе соловъев, в которой лирическая героиня признается: «Я в него влюблена, /А он любит каких-то соловьев...» ${ }^{44}$. Во второй песне Цельй день - одна забота образ Марты выдвигается на первый план. В первой песне она описана, как дочь трактирщика, «девушка с косою русой», которую Дидель покинул, а на нее засматривается «королевский красный рейтер»: он «глядит, глядит на Марту, / Крутит ус и щурит глаз». Во второй песне у нее «целый день - одна забота: / Прясть и прясть не уставая». Она влюблена в Диделя, однако лирический герой - птицелов и бродяга, он не может остаться рядом с Мартой, сердце которой хорошо понимает: «Дидель знает - это сердце / По любви своей грустит».

Завершающее стихотворение цикла датировано автором 1918 г. Багрицкий собирался назвать его Дидель, но затем все-таки отдал предпочтение заглавию, называющему не имя героя, а его занятие. Он хорошо изучил птиц, знает их повадки, время перелетов, безошибочно различает их посвисты:

Соловей ударил дудкой,

На сосне звенят синицы,

На березе зяблик бьет.

«Веселый Дидель»- хозяин этого мира. С палкой, птицей и котомкой он ходит по разным местностям и странам: через Гарц, по рейнским берегам, по Тюрингии и Саксонии, по Вестфалии и Баварии. Он весел, потому что свободен и слит с живой природой. Как отмечали авторы коллективной монографии История русской советской поэзии. 1917-1941, «...в стихах этого рода намечается очень существенная для поэзии Багрицкого идеализация “непосредственной жизни, близости к природе, ветру, солнцу, лесам”, сопровождаемая образами охоты, вольного бродяжничества» ${ }^{45}$. Несмотря на изменение социокультурной ситуации, основа жизнетворческого проекта остается прежней: «...поэтизация жизни как „кидания бездомной молодости”, романтизация бродяжничества, в котором открывается мир вольным и распахнутым, накладывает свой отпечаток и на восприятие самой революции» ${ }^{46}$. Ее участник, однако, из бродяги-птицелова превращается в бродягу-борца, как, впрочем, и его герой Тиль Уленшпигель.

43 Э.Г. Багрицкий.Собрание сочинений: в 2 m. Т. 1: Ранние стихи. Октябрь. Море. Трактир. Юro-3апад..., c. 479.

44 Там же, с. 235.

45 История русской советской поэзии. 1917--1941. Ленинград: Наука, 1983, с. 194.

46 Там же, с. 195. 
Багрицкий, как известно, был склонен к воспеванию и поэтизации бродяг и бродяжничества, притом применительно и к самому себе. В стихотворениях о Тиле Уленшпигеле именно бродяжничество дает поэту основания сопоставлять своего любимого героя с лирическим героем: «...вспоминаю / О том бродяге, что, как я, быть может, / По улицам Антверпена бродил...», «Пусть, как и тот бродяга, я пройду / По всей стране...». В творческом мире, в то же время, образ Тиля Уленшпигеля близок к Диделю, то есть птицелову, который прямо назван «бродягой»: «Я всем знаком: бродяге-птицелову...». У Багрицкого бродягой является и сам лирический герой: «Я целый день шатаюсь по дорогам...». Попытки объяснить эту особенность предпринимались неоднократно. Исследователи полагали, что бродяга, хоть и символ вольности, но индивидуалистической, он борется не за переделку общества, а за уход от него в мир природы. На наш взгляд, здесь очевидно усвоение романтической по своей сути модели поведенческой стратегии, когда поэт остается свободным творцом, не связанным с определенной социальной средой, а формой жизни является творчество, в данном случае поэтическое. Следование этой стратегии ощутимо и в поэзии, и в обычной жизни Багрицкого, построенной на отрицании материального, не подчиненной условиям привычного житейского существования. Лирический герой поэта, например, в стихотворении Осень (1916), говорит: «Я целый день шатаюсь по дорогам». Он не занят созидательным трудом, а живет лишь тем, что жертвуют ему другие: «...в мою суму дорожную бросают / Потертый грош, творожную лепешку» ${ }^{47}$. В заключительной части стихотворения автохарактеристика лирического героя дополняется такими деталями, как «...мы бродяги подбираем жадно...» и «Я, бедный странник, подымаю руки...».

И. Волгин писал, что сам поэт в обычной жизни все чаще стремился уйти от житейской суеты:

И чем неподвижнее оседает он в своей крохотной квартирке на Дальницкой улице, <..> чем плотнее окружают его литературные друзья и поклонники, делящие с ним бремя “веселой нищеты", тем бесприютнее и отчаяннее становится его лирический герой, тем охотнее вступает он в единоборство со стихией:

Ранним утром

Я уйду с Дальницкой,

дынь возьму и хлеба в узелке,

Я сегодня

Не поэт Багрицкий,

Я - матрос на греческом дубке... ${ }^{48}$

А. Карпов полагал, что в этих стихотворениях содержалась

квинтэссенция характерного для раннего Багрицкого радостного любования прекрасным, многокрасочным миром. Но гармоничность характера <...> была, в сущности, гармонией упрощенности, оказывалась искусственной. Традиционное для романтиче-

47 Э.Г. Багрицкий. Собрание сочинений: в 2 m. Т. 1: Ранние стихи. Октябрь. Море. Трактир. Юro-Запад..., c. 100.

48 И. Волгин. Эдуард Багрицкий. Стихотворения и поэмы..., с. 11. 
ской поэзии противопоставление божественного дара певца тупой сытости обывателя у Багрицкого обострялась тем, что его герой, покидая заоблачные романтические выси, выходил в жизнь» ${ }^{49}$. Однако эта жизнь, на наш взгляд, имела не много общего с реальностью: как признавался сам поэт, «события мало волновали меня. Я старался пройти мимо них ${ }^{50}$.

В стихотворениях этого периода очевидно ученичество Багрицкого не столько у конкретных поэтов-предшественников и современников, сколько у всей новейшей русской поэзии. Он отдает дань такому пониманию поэтического образа, который должен быть вещным, ясным, прозрачным, как в акмеизме, склонен к выпуклым и живописным описаниям еды, напоминающим картины фламандской школы живописи. Вместе с тем Багрицкий использует такую комбинацию средств художественной выразительности, в которой, например, плодотворные для поэтики футуризма олицетворения использованы для называния не урбанистических, а природных явлений. В ранний период творчества он прошел путь ученичества, обрел индивидуальную и неповторимую тематику и поэтику. Его стихотворения этого времени составляют важнейшую часть жизнетворческого проекта, в котором книжный мир прошлого отбрасывает свой отсвет на действительность, а герои любимых произведений отождествляются с лирическим героем поэта.

\section{Литература}

Азаров В.Б. Багрицкий и современность. «Новый мир» 1948, № 7, с. 201-214.

Азаров В.Б. Пушкинская тема в творчестве Багриикого. «Литературный современник» 1937, № 1, с. 169-174.

Аннинский Л. Э. Багрицкий: «... и труба пропела». «Литературная учеба» 2003, № 5, с. 178-195. Аннинский Л. Эдуард Багрицкий: «...и труба пропела». [В:] Аннинский Л. Красный век. Эпоха и ее поэты. В 2 книгах. Москва: ПРОЗАиК, 2009. [Online:] <https://coollib.com/b/212252/ read\#t16> (20.08.2017).

Аннинский Л.Э. Са-пож-ни-ки... «Родина» 2010, № 3, с. 23.

Антокольский П.Г. Путь поэта. [В:] Эдуард Багриикий: воспоминания современников. Москва: Советский писатель, 1973, с. 3.

Антокольский П.Г. Эдуард Багриикий. [В:] Антокольский П.Г. Поэты и время. Москва: Советский писатель, 1957, с. 85-99.

Багрицкий Э.Г. Собрание сочинений: в 2 m. Т. 1: Ранние стихи. Октябрь. Море. Трактир. ЮгоЗапад. Под ред. И. Уткина. Вступ. ст. Ю. Севрука. Москва-Ленинград: ГИХЛ, 1938.

Банчуков Р.В. Одесса - Кунцево - Вечность. [В:] Люди. Peoles.ru. [Online:] <http://www.peoples. $\mathrm{ru} /$ art/literature/poetry/contemporary/eduard_bagritskiy> (20.08.2017).

Баренбойм П. Тиль Уленшпигель времен сталинизма. «Время новостей» 2010, 16 февраля.

Богомолов Н.А. «Мы два грозой зажженные ствола...». [В:] Анти-мир русской титературы: язык, фольклор, литература. Москва: Ладомир, 1996, с. 309-337.

49 А.С. Карпов. Багрицкий Эдуард Георгиевич. [В:] Русские писатели 20 века. Биографический словарь. Гл. ред. и сост. П.А. Николаев. Москва: Научное издательство «Большая Российская энциклопедия», Издательство «Рандеву-АМ», 2000, с. 61.

50 Там же. 
Бугаева К.М. К вопросу об эволюиии романтизма Э. Багрицкого. «Вопросы русской литературы» 1966. Вып. 2, с. 73-78.

Бычкова Е.А. Жизнетворчество как феномен культуры декаданса на рубеже XIX-XX веков. Диссертация на соискание ученой степени кандидата культурологии. Специальность 24.00.01 - «Теория и история культуры». Москва, 2001.

Вайнштейн О. Жизнетворчество в культуре европейского романтизма. «Вестник РГГУ». Вып. 2: ИВГИ за письменным столом. Под ред. С.Ю. Неклюдова. Москва: Российский государственный гуманитарный университет, 1998, с. 161-186.

Винокур Г.О. Биография и культура. Русское сиеническое произношение. Москва: Русские словари, 1997, с. 17-23.

Волгин И. Эдуард Багрицкий. Стихотворения и поэмы. Сост., вступ. ст. и прим. И.Л. Волгина. Москва: Правда, 1987, с. 5-20.

Гехт С. Э.Г. Багрицкий Избранное. Москва: Правда, 1939, с. 3-12.

Горелов А. Маяковский и Багрицкий. Идеи и образы; Горелов А. Бесстрашие художника. Ленинград: Издательство писателей, 1935, с. 54-70.

Гринберг И. Эдуард Багриикий. Стихотворения и поэмы. Авт. вступ. ст. И. Гринберг. Сост. и подгот. текста В. Азарова, Е. Бургункер. Москва: Художественная литература, 1956, с. 5-35.

Гринберг И. Эдуард Багрицкий: творческий путь поэта. Ленинград: Художественная литература, 1940.

Домиль В. Удивительный мир Эдуарда Багрицкого. «Секрет» 6 августа 2010. [Online:] <http:// bagritsky.ru/articles/Udivitelnyy_mir_Aeduarda_Bagritskogo/> (20.08.2017).

Загребельный М.П. Эдуард Багриикий. Харьков: Фолио, 2012. [Online:] <http://modernlib.ru/ books/m_p_zagrebelniy/eduard_bagrickiy/read_1/> (20.08.2017).

Иоффе Д. Жизнетворчество русского модернизма subspeciesemioticae. Историографические заметки к вопросу типологической реконструкиии системы жизнь-текст. «Критика и семиотика» 2005. Вып. 8, с. 126-179.

История русской советской поэзии. 1917-1941. Ленинград: Наука, 1983.

Каракина Е. Птищелов в сетях. «Предлог» 2000, № 2, с. 180-188.

Каракина Е. По следам Юго-Запада. [Online:] <http://www.belousenko.com/books/litera/ karakina_south_west.htm> (20.08.2017).

Карпов А.С. Багриикий Эдуард Георгиевич. [В:] Русские писатели 20 века. Биографический словарь. Гл. ред. и сост. П.А. Николаев. Москва: Научное издательство «Большая Российская энциклопедия», Издательство «Рандеву-АМ», 2000, с. 60-62.

Катаев В.П. Алмазный мой венеи. Москва: Советский писатель, 1979.

Ковалева Е.А. Лексический аспект железнодорожной ситуации в поэзии Э. Багрицкого. [В:] Масловские чтения. Мурманск: Издательство Мурманского университета, 2007, c. 231-235.

Крук И.Т. Забытые странииы Э. Багриикого. «Вопросы русской литературы». Вып. 1 (4). Львов: Издательство Львовского университета, 1967, с. 47-53.

Кулагина А.А. Жизнетворческая кониепщия и принципы создания образа в лирике и драматургии Н.С. Гумилева. Диссертация на соискание ученой степени кандидата филологических наук. Специальность 10.01.01 - «Русская литература». Москва, 2012.

Литературная энциклопедия. Т. 2. Москва: Советская энциклопедия, 1929, стб. 768.

Любарева Е.П. Советская романтическая поэзия (Н. Тихонов, М. Светлов, Э. Багрицкий). 2-е изд. Москва: Высшая школа, 1973.

Любарева Е.П. Эдуард Багриикий: Жизнь и творчество. Москва: Советский писатель, 1964.

Малиновский А.А. Э. Багриикий. «Кочки». [В:] «Русский язык в школе» 2014, № 2, с. 42-45. 
Минц 3.Г. Раннее творчество Эдуарда Багрицкого. «Вестник ЛГУ» 1948, №6, с. 109-118.

Минц 3.Г., Лотман Ю.М. Статьи о русской и советской поэзии. Таллинн: Ээсти Раамат, 1989.

Михайлик Е. «Карась» глазами рыбовода. «Новое литературное обозрение» 2007, № 87, c. $104-112$.

Никольская Т.Л. Творческий путь Л.Д. Зиновьевой-Аннибал. [В:] А. Блок и революция 1905 года. Блоковский сборник 7. Тарту, 1988, с. 123-139.

Обатнина Е.А. А.М. Ремизов: жизнетворчество entrechienetloup. «Пограничное сознание. Альманах». Вып. 5. Санкт-Петербург, 1999, с. 397-424.

Олеша Ю.К. Ни дня без строчки: воспоминания. [В:] Олеша Ю.К. Зависть. Три толстяка. Ни дня без строчки. Москва: Художественная литература, 1989, с. 220-228.

Олеша Ю.К. Об Эдуарде Багрицком. «Литературный критик» 1934, № 3, с. 84-91.

Паперный В.М. Из наблюдений над поэтикой Андрея Белого: лицемерие как текстопорождающий механизм. «Славяноведение» 1992, № 6, с. 39-44.

Поступальский И. Стихи. Воспоминания о Багрицком. Вступ. слово, публ. и ком. С. Зенкевича. «Журнальный зал. Арион» 2015, № 4. [Online:] <http://magazines.russ.ru/arion/2015/4/22p. html> (20.08.2017).

Петрова Н.А. Но иногда глаза он раскрывал. Февраль и Октябрь в поэзии Эдуарда Багрицкого. «Вестник Томского государственного университета. Филология». Томск: Томский государственный университет, 2010, № 4 (12), с. 86-94.

Рождественская И.С. Поэзия Эдуарда Багрицкого. Ленинград: Художественная литература, 1967.

Святополк-Мирский Д.П. Э. Багрицкий. «Юго-Запад». [В:] Поэты и Россия: Статьи. Рецензии. Портреты. Некрологи. Санкт-Петербург: Алетейя, 2002, с. 133-136.

Синявский А.Д. Эдуард Багрицкий. [В:] История русской советской литературы. Т. 1. Москва: Изд-во АН СССР, 1958, с. 397-420.

Стратановский С. Возвращзаясь к Багрицкому. «Звезда» 2007, № 2, с. 191-208.

Фаликов И. Кидайся в края...: заметки о Багрицком. «Культура» 2004, 13-19 мая, с. 5.

Худенко Е.А. Жизнетворчество М.М. Пришвина: игровая стратегия. [Online:] <http://elar. urfu.ru/bitstream/10995/18695/1/iurg-2011-87-10.pdf> (20.08.2017).

Шохина В. Ангел смерти в кожаной тужурке. «Частный корреспондент», 3 ноября 2014. [Online:] <http://www.chaskor.ru/article/angel_smerti_v_kozhanoj_tuzhurke_20802> (20.08.2017).

Эдуард Багриикий: Альманах. Под ред. В. Нарбута. Москва: Советский писатель, 1936.

Эдуард Багрицкий: воспоминания современников. Сост. Л.Г. Багрицкая. Москва: Советский писатель, 1973.

Эренбург И. Люди, годы, жизнь: Воспоминания: в 3 m. Т. 1. Вс. ст. Б.М. Сарнова, ком. Б.Я. Фрезинского. Изд. исправл. и доп. Москва: Советский писатель, 1990.

Эренбург И. Стихотворения и поэмы. Вс. ст., сост., подг. текста и прим. Б.Я. Фрезинского. Серия «Новая библиотека поэта». Санкт-Петербург: Гуманитарное агентство «Академический Проект», 2000. 